\title{
Antioxidation activity of residue after omija (Schisandra chinensis) juice extract
}

\author{
Bo Na Park ${ }^{1} \cdot$ Jin-Won Lee ${ }^{2}$
}

\section{오미자(Schisandra chinensis) 착즙박 추출물의 항산화 활성}

\author{
박보나 ${ }^{1}$ 이진원 ${ }^{2}$
}

Received: 28 December 2016 / Accepted: 4 February 2017 / Published Online: 30 June 2017

(C) The Korean Society for Applied Biological Chemistry 2017

\begin{abstract}
The physicochemical properties and schizandrin contents of various solvent $\left(\mathrm{H}_{2} \mathrm{O}, 50 \% \mathrm{EtOH}, 75 \% \mathrm{EtOH}, 95 \%\right.$ $\mathrm{EtOH})$ extracts from residue after Omija juice was investigated using total polyphenol contents (TOC), 2,2-diphenyl-1-picrylhydrazyl (DPPH) free radical scavenging activity (RAS), anthocyanin contents (ANC), and schizandrin contents level (SCL). Total polyphenol contents, radical scavenging activity, and anthocyanin contents of $50 \%$ EtOH extract were the highest among all residue after Omija juice extracts, and was $16.70 \mathrm{mg} / \mathrm{mL}$ in the TOC and $86.16 \%$ in the DPPH-RAS. This meant that $50 \% \mathrm{EtOH}$ extract from residue after Omija juice had more available antioxidant matters. As extraction time increases all extract treatments significantly reduced in the ANC contents $(p<0.05)$. Amount of the SCL were observed higher value in $95 \%$ EtOH extract of residue after Omija juice.
\end{abstract}

Keywords Electron donating ability · Omija · Residue after omija juice $\cdot$ Schizandrin $\cdot$ Total polyphenol

Jin-Won Lee $(\bowtie)$

E-mail:1jw7542@hanmail.net

${ }^{1}$ Department of Food \& Biotechnology and Biotechnology Graduate School, Hankyong National University, Anseong 17579, Republic of Korea

${ }^{2}$ Faculty of Health \& Food/Medicinal Plant, Suwon Women's University, Suwon-Si 16632, Republic of Korea

This is an Open Access article distributed under the terms of the Creative Commons Attribution Non-Commercial License (http://creativecommons. org/licenses/by-nc/3.0/) which permits unrestricted non-commercial use, distribution, and reproduction in any medium, provided the original work is properly cited.
서 론

오미자는 오미자 나무과(Schisandraceae)에 속하는 낙엽성 목본 의 덩굴성 식물로 둥근 형태의 붉은색 과실이다(Jung 등, 2000; Mok 2005). 오미자는 6-8월에 개화하여 9-10월에 과실이 열리 고 서리가 내린 후, 채취하여 사용하며, 오미자 과육은 달고도 신맛을 나타내며, 핵중은 맵고도 떫으며 또한 쓴맛이 합해져서 다섯 가지의 맛이라고 하여 그 명칭이 유래되었다(Moon 등, 2003; Jeong 등 2006). 오미자의 주요 기능성 성분으로는 리그난 화합 물이 알려져 있으며, schizandrin, gomisin N 및 gomisin A가 가장 많이 함유되어 있으며(Yukinobu 등, 1979; Sohn and Bock $1989 ; \mathrm{Kim}$ 등, 2002), 오미자의 붉은색은 $80 \%$ 이상이 anthocyanin 의 함유로 인한 것이며, 이러한 anthocyanin은 peonidin 3glucoside인 것으로 보고되고 있다(Song 1982). 이와 같은 기능 성 성분이 함유된 오미자를 이용하여 다양한 연구가 진행되고 있으며, 특히, 알코올 해독작용 및 간 보호 효과(Lee와 Lee 1990; Kim 등, 2000), 간암세포에 대한 항암효과(Rho 등, 2002), 대장암세포 증식억제효과(Ryu와 Chung 2011), 고지혈증 완화(Ock 1995), 혈당 및 혈압강하 등에 효과가 있다는 연구보 고가 알려져 있다(Whang 2002; Ko 등, 2004; Kim 등, 2009).

또한, 이러한 오미자의 기능성은 최근 천연 항산화제에 대한 연구가 활발히 이루어지면서 항산화 효과를 갖고 있는 천연 재 료로 관심이 증가하고 있다. 일반적으로 천연 재료에서의 항산 화 효과를 알아보기 위해서는 다양한 용매를 이용하여 천연 재 료를 추출하는 방법을 이용하여 항산화 효과를 측정하는 연구 가 대부분이다. 이에 오미자를 열수 $\left(\mathrm{H}_{2} \mathrm{O}\right)$ 및 에탄올 $(\mathrm{EtOH})$ 을 이용하여 추출한 오미자 추출물의 항산화 효과를 알아본 연구 보고가 있다. 즉, 오미자를 열수 및 에탄올을 이용하여 추출한 다음 추출물 각각에 대한 항산화 효과를 알아본 결과 열수 추 출물보다 에탄올 추출물의 항산화 효과가 더 높게 나타났으며, 상온일 때 보다 가온을 한 경우 더 높은 항산화 효과를 나타내 
는 것으로 보고되고 있다(Kwon과 Park 2006; Kim 등, 2009; Kim과 Park 2010). 또한, 오미자의 기능성 성분은 과육보다는 종자에 많이 함유된 것으로 보고되어 있다(Choi 등, 2011; Kim 등, 2013). 또한, 오미자 종자에 함유된 기능성 성분을 분석하 는 연구보고 중 오미자 종자의 분쇄 후 용매추출을 이용하여 제조한 추출물에 대하여 항염증 효과에도 탁월한 효과가 더욱 증가한다는 연구 보고가 있다(Kwon 등, 2001; Choi 등, 2013). 이와 같이 오미자에 관한 기능성 연구가 활발히 진행되면서 주로 약용작물로 사용되어 왔던 오미자를 활용하여 다양한 음 료에 대한 수요와 공급이 증가하게 되고, 오미자의 재배, 생산 확대와 더불어 농산업의 고부가가치 작물로 자리매김 하고 있 다. 그러나 오미자 유통 시 $80 \%$ 이상이 생과 형태로 하고 있 으며, $20 \%$ 정도만 건조 또는 액즙 형태로 가공하여 판매하고 있다(Kim 등, 2012). 일반적으로 시중에서 쉽게 접할 수 있는 오미자는 저장성을 증가시킨 건조된 오미자이기 때문에 생 오 미자에 대한 연구보다는 대부분이 건 오미자를 이용한 연구 보 고이다. 또한, 생 오미자를 이용하여 연구한 보고에서도 대부분 착즙 공정을 거쳐 생산된 가공품에 대한 연구 자료일 뿐 생 오 미자에 대한 연구가 많이 부족한 실정이다. 따라서, 본 연구에 서는 생 오미자를 착즙하고 남은 착즙박에 대한 항산화적 특성 및 기능성 성분 중 하나인 schizandrin 함량을 측정하여 생 오 미자의 특성을 알아보고자 한다. 즉, 생 오미자의 착즙 후 버려 지는 많은 양의 착즙박을 가공식품의 원료로 이용할 수 있는지 에 대한 가능성을 알아봄으로써 생 오미자 착즙박에 대한 활용 도를 증가시킬 수 있으며, 오미자를 생산하는 농가에 대한 경 제적 성장에 도움을 주고자 한다.

\section{재료 및 방법}

\section{실험 재료}

본 실험에서 사용한 오미자는 전라북도 장수군에서 수확(2014 년 9월)한 생 오미자를 구입하여 사용하였다.

\section{생 오미자 착즙박 추출물 제조}

생 오미자를 가지와 열매를 분리한 후, 착즙기(Hurom-HL Series, Seoul, Korea)를 이용하여 생 오미자 착즙박을 분리하였 다. 분리된 생 오미자 착즙박 $15 \mathrm{~g}$ 에 각각의 용매(열수: $\mathrm{A}$, $50 \%$ 에탄올: $\mathrm{B}, 70 \%$ 에탄올: $\mathrm{C}, 95 \%$ 에탄올: $\mathrm{D}$ )를 착즙박 사 용량에 대하여 10 배 비율로 가한 후, $60^{\circ} \mathrm{C}$ 항온수조에서 1 시간 부터 10 시간까지 1 시간 간격으로 정치 추출 $\left(60^{\circ} \mathrm{C}\right)$ 하였다. 추 출한 시료는 filter paper (Hyundai Micro Co., Ltd., Seoul, Korea, No. $20(90 \mathrm{~mm}, 5-8 \mu \mathrm{m})$ 를 이용하여 감압 여과하였으 며, 분리 된 여과액은 감압 농축기 (HS-2005S-N, Hahn Shin Scientific Co., Gyeonggi, Korea)를 이용하여 농축한 후 시료로 사용하였다.

\section{생 오미자 착즙박의 일반성분 분석}

생 오미자 착즙박의 일반성분 분석은 식품공전에 제시된 방법 으로 수분, 조지방, 조단백질 및 조회분을 분석하였다. 수분은
Table 1 Conditions for schizandrin analysis by HPLC

\begin{tabular}{ll}
\hline \multicolumn{1}{c}{ Instrument } & \multicolumn{1}{c}{ Conditions } \\
\hline Column & C18 Symmetry ${ }^{\circledR} \mu \mathrm{m}(4.6 \times 250 \mathrm{~mm})$ \\
Detector & UV/Vis detector $254 \mathrm{~nm}$ \\
Column temp. & $25^{\circ} \mathrm{C}$ \\
Flow rate & $1.0 \mathrm{~mL} / \mathrm{min}$ \\
Mobile phase & $60: 40=$ Acetonitril : Water $(\mathrm{v} / \mathrm{v})$ \\
\hline
\end{tabular}

상압가열 건조법을 이용하여 $105^{\circ} \mathrm{C}$ 건조기를 이용하여 건조 전 후의 무게 차이에 대한 결과를 측정하여 알아보았으며, 조지방 함량은 soxhlet 추출법으로 측정하였다. 조단백질 함량은 semimicro kjeldahl법에 의해 측정하였고, 조회분 함량은 550 ${ }^{\circ} \mathrm{C}$ 직접 회화법을 이용하여 측정하였다.

\section{생 오미자 착즙박의 Schizandrin 함량분석}

생 오미자 착즙박 추출물의 schizandrin 함량 측정은 $\mathrm{Kim}$ 등 (2013) 방법을 변형하여 시행하였다. 표준품은 schizandrin (Wako pure chemical, Osaka, Japan) $10 \mathrm{mg}$ 을 99\% 메탄올 $10 \mathrm{~mL}$ 에 용해시킨 것을 표준액 $(1000 \mathrm{ppm})$ 으로 하여 이를 5 , $10,20,40,80,100 \mathrm{ppm}$ 으로 희석하여 검량선을 작성 하였으며, 시료의 전처리는 $99 \%$ HPLC grade 메탄올을 이용하여 50배 희석하여, 그 상등액을 취해 사용하였다. schizandrin 분석을 위 해 사용된 기기는 HPLC (Waters 2690, Waters Co., Miliford, MA, USA)을 이용하여 UV-Vis Detector (Waters ${ }^{\mathrm{TM}}$ 486, Waters $\mathrm{Co}$.)로 측정하였으며, 분석조건은 Table 1 과 같다.

\section{총 폴리페놀(total polyphenol) 함량 측정}

Folin-Denis 방법(Singleton and Rossi 1965)을 변형하여 사용하 였으며, 오미자 착즙박 추출물을 증류수로 희석한 용액을 $2 \%$ Sodium carbonate solution (Yakuri Fure Chemicals Co., Ltd., Osaka Japan)을 첨가 후, 상온에서 3분간 방치하고 $1 \mathrm{~N}$ Folinciocalteu's phenol rengent (Sigma Co., Flawil, Swizerland)를 가하여 혼합하였다. 이 혼합액을 $37{ }^{\circ} \mathrm{C}$ 항온수조에서 30 분간 방 치한 다음, UV-Vis spectrophotometry (Optizen POP., Mecasys Co., Ltd., Daejeon, Korea)로 $725 \mathrm{~nm}$ 에서 흡광도를 측정하였다. 표준곡선은 tannic acid (Sigma Co., St. Louis, USA)를 표준 물질로 검량선을 작성하여 총 폴리페놀 함량을 계산하였다. 각 시험은 3 회 반복하여 수행하였다.

\section{DPPH를 이용한 항산화눙 측정}

2,2-diphenyl-1-picrylhydrazyl (DPPH)에 대한 전자공여능(electron donating ability, EDA)은 Blois 등(1958)의 방법을 응용하여 측 정하였다. 즉 $0.1 \mathrm{mM} \mathrm{DPPH}$ 용액을 제조하여, 생 오미자의 착 즙박 추출물을 $\mathrm{DPPH}$ 용액과 혼합한 후 30 분간 반응 시키고 $517 \mathrm{~nm}$ 에서 UV-Vis spectrophotometry (Optizen POP., Mecasys Co., Ltd.)를 이용하여 흡광도를 측정하였으며, 증류수를 동일하 게 처리하여 대조구의 흡광도를 동일한 조건에서 측정하였다. 비교구로 ascorbic acid를 이용하여 위와 동일한 방법으로 전자 공여능을 측정하여 시료군과 비교하였고, 각 시험은 3 회 반복하 여 수행하였다. 전자공여능은 아래의 식을 이용하여 산출하였다. 
Electron donating ability (EDA, \%)

$$
=1-(\text { Sample O.D. }) /(\text { Control O.D. }) \times 100
$$

Sample O.D.: 시료를 가한 시험액의 흡광도

Control O.D.: 시료 대신 에탄올을 가한 시험액의 흡광도

\section{총 안토시아닌(total anthocyanin) 함량 측정}

총 안토시아닌 정량은 Park과 $\operatorname{Hong}(2014)$ 의 방법을 이용하여 측정하였다. $0.2 \mathrm{M} \mathrm{HCl}$ 을 첨가하여 $\mathrm{pH} 1.0$ 을 맞춘 $0.2 \mathrm{M} \mathrm{KCl}$ (A용액)과 $0.2 \mathrm{M} \mathrm{NaOH}$ 를 첨가하여 $\mathrm{pH} 4.5$ 를 맞춘 $0.2 \mathrm{M}$ $\mathrm{KH}_{2} \mathrm{PO}_{4}$ (B용액)를 제조한 후, 생 오미자 착즙박 추출물에 $\mathrm{A}$ 용 액과 $\mathrm{B}$ 용액을 각각 첨가 후 혼합한 다음 UV-Vis spectrophotometry (Optizen POP., Mecasys Co., Ltd.)로 $520 \mathrm{~nm}$ 와 700 $\mathrm{nm}$ 에서 흡광도를 측정한 후, 아래의 식을 이용하여 안토시아닌 함량을 계산하였다. 각 시험은 3회 반복하여 수행하였다.

Total anthocyanin content $(\mathrm{mg} / \mathrm{kg})$

$$
=((520 \mathrm{~nm}-700 \mathrm{~nm}) \mathrm{Abs}-(520 \mathrm{~nm}-700 \mathrm{~nm}) \mathrm{Abs}) \times 449.2
$$$$
\times \text { 희석배수 } \times 1000 / 26900 \times 5
$$

449.2: cyanidin-3-glucoside의 $1 \mathrm{~mol}$ 당 분자량 $(\mathrm{g})$ 26900: cyanidin-3-glucoside molar abosorbance 5: 최종시료 부피

\section{통계 처리}

실험결과는 SAS (Statistical Analysis System, 6.30, USA) 통 계 Package(1988)를 사용하여 각각의 분석 데이터를 통계분석 하였으며, Duncan 다 범위 검증(Duncan's multiple range test) 을 이용하여 $p<0.05$ 의 수준에서 통계학적 유의성을 검정하였다.

\section{결과 및 고찰}

\section{생 오미자 착즙박의 일반성분 분석}

생 오미자 $(450 \mathrm{~g})$ 를 착즙기로 착즙한 후 남은 착즙박에 대한 일 반성분을 분석하였다. 생 오미자 $450 \mathrm{~g}$ 에 대하여 착즙박 수율은 $27.67 \%$ 를 나타내었으며, 각각의 추출 용매에 따른 생 오미자 착즙박의 추출 수율은 열수를 이용하여 추출한 경우는 18.43 ,
Table 2 General components of raw Omija and residue after Omija juice extraction

\begin{tabular}{lcc}
\hline \multirow{2}{*}{ General components } & \multicolumn{2}{c}{ Contents $(\mathrm{g} / 100 \mathrm{~g})$} \\
\cline { 2 - 3 } & Raw Omija & $\begin{array}{c}\text { Residue after } \\
\text { Omija juice extraction }\end{array}$ \\
\hline Moisture & 77.27 & 55.30 \\
Crude fat & 5.84 & 9.34 \\
Crude protein* & 1.36 & 6.22 \\
Ash & 0.68 & 0.86 \\
\hline
\end{tabular}

${ }^{*}$ Crude protein: Nitrogen content $\times 6.25$

50,70 및 $95 \%$ 에탄올을 이용하여 추출한 경우에는 각각 9.18 , 9.94 및 $10.61 \%$ 를 나타내었다. 생 오미자 착즙박의 일반성분의 분석결과를 비교하기 위하여 생 오미자의 일반성분 분석결과를 Table 2에 함께 나타내었다. 생 오미자 착즙박의 수분함량은 $55.3 \%$, 조지방 $9.3 \%$, 조단백질 $6.2 \%$ 및 조회분 $0.9 \%$ 를 나타내 었다. $\operatorname{Kim}$ 등 $(2000)$ 이 보고한 생 오미자의 일반적인 일반성분 함량은 수분 $84.2 \%$, 조지방 $0.9 \%$, 조단백질 $1.1 \%$ 의 결과를 보 이고, Choi 등(2008) 에서는 수분 $79.6 \%$, 조지방 $1.2 \%$, 조단백 질 $1.7 \%$ 및 조회분 $0.6 \%$ 의 결과를 보고하였다. 생 오미자 착 즙박의 일반성분 분석결과는 생 오미자보다 수분은 $22 \%$ 감소 하고, 조지방은 $3.5 \%$ 증가했으며, 조단백질은 $4.8 \%$ 증가하고, 조회분은 $0.2 \%$ 증가했다. 이는 착즙 과정에서 착즙액과 착즙박 으로 분리됨에 따라서 수분함량에 대한 변화가 가장 크게 나타 난 것으로 판단되었으며, 조지방의 경우 생 오미자의 씨앗 부 분이 파쇄되면서 착즙박 부분으로 함유되면서 조지방의 함량에 영향을 미친 것으로 생각되었다.

\section{생 오미자 착즙박의 용매별 추출물의 schizandrin 분석}

생 오미자 착즙박의 용매별(열수: A, $50 \%$ 에탄올: $\mathrm{B}, 70 \%$ 에탄 올: C, $95 \%$ 에탄올: D) 추출물의 schizandrin 함량 측정 결과 는 Table 3에 나타내었다. 오미자 착즙박을 추출 용매에 따라 서 각각 1 시간에서 10 시간까지 추출하여 schizandrin 함량을 분 석한 결과 추출시간에 따른 schizandrin 함량의 변화는 유의적 차이를 나타내지는 않았다. 즉, A 용매를 이용하여 추출한 경

Table 3 Changes of schizandrin contents of residue after Omija juice extraction by different extraction methods

\begin{tabular}{ccccc}
\hline \multirow{2}{*}{ Extraction time $(\mathrm{h})$} & \multicolumn{4}{c}{ Schizandrin $(\mathrm{g} / 100 \mathrm{~g})$} \\
\cline { 2 - 5 } & $\mathrm{H}_{2} \mathrm{O}$ & $50 \% \mathrm{EtOH}$ & $70 \%$ EtOH & $95 \%$ EtOH \\
\hline 1 & $0.52 \pm 0.06^{\mathrm{aCl} 1}$ & $1.79 \pm 0.21^{\mathrm{aB}}$ & $2.01 \pm 0.19^{\mathrm{aAB}}$ & $2.37 \pm 0.31^{\mathrm{aA}}$ \\
2 & $0.58 \pm 0.03^{\mathrm{aB}}$ & $1.74 \pm 0.50^{\mathrm{aA}}$ & $2.03 \pm 0.12^{\mathrm{aA}}$ & $2.46 \pm 0.56^{\mathrm{aA}}$ \\
3 & $0.43 \pm 0.04^{\mathrm{aB}}$ & $1.89 \pm 0.71^{\mathrm{aA}}$ & $1.90 \pm 0.30^{\mathrm{aA}}$ & $2.68 \pm 0.23^{\mathrm{aA}}$ \\
4 & $0.64 \pm 0.23^{\mathrm{aB}}$ & $1.91 \pm 0.35^{\mathrm{aA}}$ & $2.12 \pm 0.53^{\mathrm{aA}}$ & $2.50 \pm 0.22^{\mathrm{aA}}$ \\
5 & $0.58 \pm 0.16^{\mathrm{aC}}$ & $1.81 \pm 0.20^{\mathrm{aB}}$ & $2.18 \pm 0.23^{\mathrm{aAB}}$ & $2.51 \pm 0.42^{\mathrm{aA}}$ \\
6 & $0.52 \pm 0.05^{\mathrm{aC}}$ & $1.67 \pm 0.35^{\mathrm{aB}}$ & $1.93 \pm 0.05^{\mathrm{aAB}}$ & $2.48 \pm 0.51^{\mathrm{aB}}$ \\
7 & $0.65 \pm 0.22^{\mathrm{aC}}$ & $1.67 \pm 0.04^{\mathrm{aB}}$ & $2.13 \pm 0.19^{\mathrm{aAB}}$ & $2.40 \pm 0.50^{\mathrm{aA}}$ \\
8 & $0.64 \pm 0.28^{\mathrm{aC}}$ & $1.74 \pm 0.40^{\mathrm{aB}}$ & $1.96 \pm 0.14^{\mathrm{aAB}}$ & $2.30 \pm 0.14^{\mathrm{aA}}$ \\
10 & $0.67 \pm 0.31^{\mathrm{aB}}$ & $1.99 \pm 0.36^{\mathrm{aA}}$ & $2.11 \pm 0.11^{\mathrm{aA}}$ & $2.27 \pm 0.43^{\mathrm{aA}}$ \\
\hline
\end{tabular}

\footnotetext{
${ }^{1}$ Means \pm standard deviation $(n=3)$
}

Superscript letters in a column (a) and a row (A-C) indicate significantly at $p<0.05$ by Duncan's multiple comparison 
Table 4 Changes of total polyphenol contents of residue after Omija juice extraction by different extraction methods

\begin{tabular}{ccccc}
\hline \multirow{2}{*}{ Extraction time $(\mathrm{h})$} & \multicolumn{4}{c}{ Total Polyphenol $(\mathrm{mg} / \mathrm{mL})$} \\
\cline { 2 - 5 } & $\mathrm{H}_{2} \mathrm{O}$ & $50 \%$ EtOH & $70 \%$ EtOH & $95 \%$ EtOH \\
\hline 1 & $5.20 \pm 1.11^{\mathrm{aCl}}$ & $16.70 \pm 0.60^{\mathrm{aA}}$ & $15.94 \pm 0.54^{\mathrm{aA}}$ & $10.65 \pm 2.09^{\mathrm{aB}}$ \\
2 & $5.34 \pm 0.20^{\mathrm{aC}}$ & $17.03 \pm 2.35^{\mathrm{aA}}$ & $17.08 \pm 0.61^{\mathrm{aA}}$ & $11.07 \pm 2.08^{\mathrm{aB}}$ \\
3 & $5.11 \pm 0.38^{\mathrm{aC}}$ & $17.67 \pm 4.13^{\mathrm{aA}}$ & $15.92 \pm 0.38^{\mathrm{aA}}$ & $10.13 \pm 0.60^{\mathrm{aB}}$ \\
4 & $6.03 \pm 1.75^{\mathrm{aC}}$ & $17.64 \pm 0.10^{\mathrm{aA}}$ & $16.25 \pm 0.65^{\mathrm{aA}}$ & $10.80 \pm 1.36^{\mathrm{aB}}$ \\
5 & $6.20 \pm 3.45^{\mathrm{aB}}$ & $17.39 \pm 3.36^{\mathrm{aA}}$ & $15.68 \pm 1.39^{\mathrm{aA}}$ & $9.69 \pm 0.32^{\mathrm{aB}}$ \\
6 & $5.37 \pm 0.96^{\mathrm{aC}}$ & $16.78 \pm 2.31^{\mathrm{aA}}$ & $16.91 \pm 1.31^{\mathrm{aA}}$ & $12.47 \pm 1.49^{\mathrm{aB}}$ \\
7 & $5.85 \pm 1.35^{\mathrm{aC}}$ & $16.57 \pm 0.65^{\mathrm{aA}}$ & $16.23 \pm 0.83^{\mathrm{aA}}$ & $12.23 \pm 1.96^{\mathrm{aB}}$ \\
8 & $5.84 \pm 1.36^{\mathrm{aC}}$ & $18.43 \pm 2.82^{\mathrm{aA}}$ & $16.98 \pm 0.43^{\mathrm{aA}}$ & $10.84 \pm 1.55^{\mathrm{aB}}$ \\
9 & $6.97 \pm 2.67^{\mathrm{aB}}$ & $17.47 \pm 2.14^{\mathrm{aA}}$ & $16.99 \pm 1.50^{\mathrm{aA}}$ & $9.90 \pm 0.51^{\mathrm{aB}}$ \\
10 & $5.57 \pm 1.70^{\mathrm{aC}}$ & $15.96 \pm 1.84^{\mathrm{aA}}$ & $15.33 \pm 1.25^{\mathrm{aAB}}$ & $12.18 \pm 0.68^{\mathrm{aB}}$ \\
\hline
\end{tabular}

${ }^{1}$ Means \pm standard deviation $(n=3)$

Superscript letters in a column (a-b) and a row (A-C) indicate significantly at $p<0.05$ by Duncan's multiple comparison

우 1 시간 동안 추출한 추출액과 10 시간 동안 추출한 추출액에 함유된 schizandrin 함량은 각각 $0.52 \mathrm{~g} / 100 \mathrm{~g}$ 및 $0.48 \mathrm{~g} / 100 \mathrm{~g}$ 이 었으며, B 용매에서는 $1.79 \mathrm{~g} / 100 \mathrm{~g}$ 및 $2.01 \mathrm{~g} / 100 \mathrm{~g}$ 을 나타냈으 며, C 용매에서는 $2.01 \mathrm{~g} / 100 \mathrm{~g}$ 및 $2.09 \mathrm{~g} / 100 \mathrm{~g}$, D 용매에서는 $2.37 \mathrm{~g} / 100 \mathrm{~g}$ 및 $2.47 \mathrm{~g} / 100 \mathrm{~g}$ 의 함량을 나타내었다. 이와 같은 결과를 살펴본 결과 추출 시간이 추출 용매에 대해서는 큰 영 향을 나타내지 않았으며, 추출용매 종류별에 따라서 schizandrin 함량은 $\mathrm{A}<\mathrm{B}<\mathrm{C}<\mathrm{D}$ 순서대로 변화를 나타내었다. Park 등 (2013)의 연구에 따르면 오미자를 열수를 이용하여 추출한 경 우 schizandrin, gomisin $\mathrm{N}$, 및 gomisin $\mathrm{A}$ 의 총 함량 차이가 10 분 동안 추출한 경우 $0.49 \mathrm{~g} / 100 \mathrm{~g}, 12$ 시간 추출한 경우 $0.48 \mathrm{~g} / 100 \mathrm{~g}$ 및 24시간 추출한 경우 $0.55 \mathrm{~g} / 100 \mathrm{~g}$ 결과를 나타 내었다고 보고된 결과와 같이 동일 용매에 대한 추출시간에 따 른 schizandrin 함량은 크게 영향을 받지 않음을 알 수 있었다. 따라서 본 연구의 오미자 착즙박을 용매별로 추출하여 schizandrin 을 추출할 경우 1 시간 추출조건이 충분할 것으로 판 단되었다.

\section{생 오미자 착즙박의 용매별 추출물의 총 폴리페놀 측정}

생 오미자 착즙박의 용매별(열수: $\mathrm{A}, 50 \%$ 에탄올: $\mathrm{B}, 70 \%$ 에 탄올: C, $95 \%$ 에탄올: D) 추출물에 대한 총 폴리페놀 측정 결 과 Table 4 와 같다. B 용매인 $50 \%$ 에탄올를 이용하여 1 시간 동안 추출한 경우 가장 높은 총 폴리페놀 함량을 나타내었다. 즉, 1 시간 동안 다양한 용매를 이용하여 오미자 착즙박을 추출 하여 총 폴리페놀 함량을 측정한 결과 $\mathrm{A}$ 용매 추출물은 $5.20 \mathrm{mg} / \mathrm{mL}, \mathrm{B}$ 용매 추출물은 $16.70 \mathrm{mg} / \mathrm{mL}, \mathrm{C}$ 용매 추출물은 $15.94 \mathrm{mg} / \mathrm{mL}$ 및 $\mathrm{D}$ 용매 추출물은 $10.65 \mathrm{mg} / \mathrm{mL}$ 의 함량을 나타 냈다. Kwon과 Park(2006)의 연구에서도 건 오미자를 이용하여 $\mathrm{H}_{2} \mathrm{O}$ 와 $70 \%$ 에탄올 용매를 이용하여 각각 $80,70{ }^{\circ} \mathrm{C}$ 에서 추출 한 추출물에 대한 총 폴리페놀 함량을 측정한 결과 열수 추출 물은 $5.12 \mathrm{mg} / \mathrm{mL}$ 및 $70 \%$ 에탄올 추출물은 $6.97 \mathrm{mg} / \mathrm{mL}$ 의 함 량을 나타내었다는 연구보고가 있다. 이와 같은 결과는 본 연 구에서 열수를 추출용매로 이용하여 오미자 착즙박을 추출한 경 우 측정된 총 폴리페놀 함량 $(5.20 \mathrm{mg} / \mathrm{mL})$ 과 유사한 결과를 나 타내었다. 또한, 에탄올 용매를 이용하여 오미자 착즙박을 추출 하여 총 폴리페놀 함량을 측정한 결과 50,70 및 $90 \%$ 에탄올
모두에서 열수 추출물에서 보다는 훨씬 높게 나타났다. 특히, $70 \%$ 에탄올을 이용하여 추출한 경우 총 폴리페놀 함량이 가장 높게 추출된 것을 알 수 있었다. 오미자 착즙박의 경우는 과육 및 과피 뿐 만 아니라 유지 성분이 함유되어 있는 씨 부분까지 함유되어 열수 보다는 에탄올를 이용한 경우 유효성분에 대한 추출 효과가 증가된 것으로 판단되었다.

\section{생 오미자 착즙박의 용매별 추출물의 DPPH를 이용한 항산화 능 측정}

생 오미자 착즙박의 용매별(열수: $\mathrm{A}, 50 \%$ 에탄올: $\mathrm{B}, 70 \%$ 에 탄올: $\mathrm{C}, 95 \%$ 에탄올: $\mathrm{D})$ 추출물 $(0.2 \mathrm{mg} / \mathrm{mL})$ 에 대한 $\mathrm{DPPH}$ 전자공여소거능을 측정하였으며, 그 결과는 Fig. 1과 같다. 각 각의 추출 용매를 이용하여 오미자 착즙박을 1 시간에서 10 시간 동안 추출하여 $\mathrm{DPPH}$ 전자공여소거능을 측정한 결과 추출 용 매에 따라서 $\mathrm{B}>\mathrm{C}>\mathrm{D}>\mathrm{A}$ 순으로 높게 나타났다. 즉, $\mathrm{A}$ 용매 추출액에 대한 $\mathrm{DPPH}$ 전자공여소거능은 1시간 추출경우 $29.96 \%$ 및 10 시간 추출경우 $30.15 \%$ 를 나타내었으며, B 용매 추출액에 대해서는 1 시간 추출경우 $86.16 \%$ 및 10 시간 추출경우 $88.24 \%$ 을 나타냈고, C 용매 추출액은 1시간 추출경우에서 $84.84 \%, 10$ 시간 추출경우 $83.75 \%$ 를 나타내었다. 또한, D 용매 추출액을 이용하여 추출한 추출액의 경우 1 시간 및 10 시간 추출경우 각 각 62.72 와 $71.86 \%$ 의 $\mathrm{DPPH}$ 전자공여소거능에 대한 효과를 나 타내었다. 또한, 열수 를 추출 용매로 이용하여 오미자 착즙박 을 추출하여 $\mathrm{DPPH}$ 전자공여소거능에 대한 효과를 측정한 경 우 4시간 추출 시 다소 증가하는 경향을 나타내었으나, 유의적 차이는 나타내지 않았다. 이러한 결과를 살펴본 결과 오미자 착 즙박에 용매를 처리하여 추출한 추출액에 대한 $\mathrm{DPPH}$ 전자공 여소거능 효과에 대해서는 추출시간에 대한 영향은 크지 않음 을 알 수 있었다. 그리고, 에탄올 농도를 달리하여 오미자 착즙 박을 추출하여 제조한 추출물에 대한 $\mathrm{DPPH}$ 전자공여소거능 효 과를 알아본 결과 50 및 $70 \%$ 에탄올을 이용하여 추출한 추출 물의 경우 열수를 추출 용매로 이용한 경우 보다 최대 2.9 배 정도 효과를 나타냄을 알 수 있었으며, $95 \%$ 에탄올에 비하여 50 및 $70 \%$ 에탄올을 이용한 경우 오미자 착즙박 추출물에 대 한 $\mathrm{DPPH}$ 전자공여소거능 효과가 다소 높게 나타난 결과를 살 펴볼 때, 추출 용매의 에탄올 함량의 증가가 $\mathrm{DPPH}$ 전자공여소 


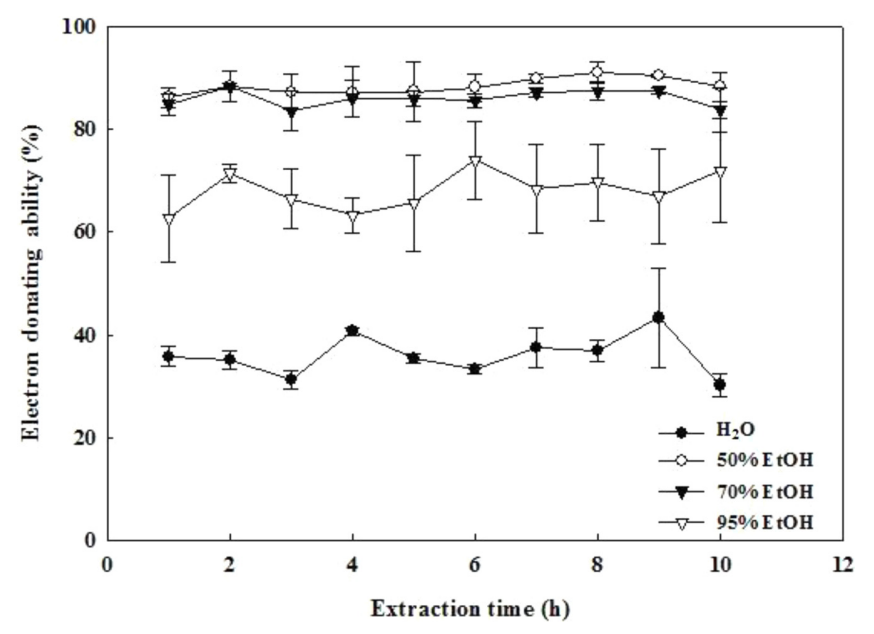

Fig. 1 Changes of DPPH radical scavenging activity of residue after Omija juice extract by different extraction methods

거능 효과를 증가시키는데 영향을 미치지 않는다는 것을 알 수 있었다. 이와 같은 결과는 Chun 등(2003)이 보고한 연구결과에 서 동결 건조한 오미자로부터 용매의 농도에 따른 추출특성을 비교한 결과, $80 \%$ 에탄올 용매 추출물보다 $50 \%$ 에탄올 용매 추출물이 높은 $\mathrm{DPPH}$ 전자공여소거능을 나타내어 본 연구와 유 사한 경향을 보였으며, $\mathrm{Kim}$ 등(2009)에서는 건 오미자를 $60{ }^{\circ} \mathrm{C}$ 에서 열수와 $60 \%$ 에탄올로 추출 하였을 때 $60 \%$ 에탄올 추출 물이 열수 추출물보다 4 배 이상의 효능을 보였다는 결과와 유 사한 경향을 나타내고 있다. 또한, $50 \%$ 에탄올 및 $70 \%$ 에탄올 을 이용하여 추출한 오미자 착즙박 추출물 $(0.2 \mathrm{mg} / \mathrm{mL})$ 의 $\mathrm{DPPH}$ 전자공여소거능 $(88.24$ 및 $84.84 \%)$ 과 ascorbic acid $(0.04$, $0.05 \mathrm{mg} / \mathrm{mL})$ 의 $\mathrm{DPPH}$ 전자공여소거능 $(75.55,95.23 \%)$ 을 비교한 결과 ascorbic acid 용액과 오미자 착즙박 추출물의 농도에 대 한 차이는 있으나, 오미자 착즙박 추출물이 정제 과정 없는 천 연 물질이라는 점을 고려해 볼 때, 천연 항산화제로의 가능성 을 갖고 있음을 확인할 수 있었다.

\section{생 오미자 착즙박의 용매별 추출물의 안토시아닌 함량 측정}

생 오미자 착즙박의 용매별(열수: $\mathrm{A}, 50 \%$ 에탄올: $\mathrm{B}, 70 \%$ 에 탄올: C, $95 \%$ 에탄올: D) 추출물에 대한 안토시아닌 함량 결 과 Table 5와 같다. 추출시간에 따른 추출 용매별 안토시안 함 량은 $\mathrm{A}$ 용매를 이용한 경우 1 시간 동안 추출한 추출물 $(66.46$ $\mathrm{mg} / \mathrm{kg}$ )과 5 시간 추출한 추출물 $(54.44 \mathrm{mg} / \mathrm{kg})$ 을 제외하고 나머 지 시간에서는 유의적 차이를 보이지 않았으며, B 용매는 1시 간에서 6시간 동안 추출한 추출물의 경우 각각 101.70 및 $87.50 \mathrm{mg} / \mathrm{kg}$ 를 나타내면서 큰 유의적 차이가 없다가 10 시간 동 안 추출한 추출물의 경우 $47.93 \mathrm{mg} / \mathrm{kg}$ 으로 급격히 감소하는 경 향을 나타내었다. C 용매를 이용한 경우에는 1 시간 동안 추출 한 추출물의 경우 $109.32 \mathrm{mg} / \mathrm{kg}$ 의 안토시아닌 함량을 나타내다 가 10 시간 추출 시 $69.13 \mathrm{mg} / \mathrm{kg}$ 으로 감소하는 경향을 보였으며, $\mathrm{D}$ 용매인 $95 \%$ 에탄올을 이용하여 1시간 추출한 추출물의 경 우 $65.46 \mathrm{mg} / \mathrm{kg}$ 에서 추출 8 시간부터 $38.07 \mathrm{mg} / \mathrm{kg}$ 으로 감소하다 가 추출 10 시간의 경우 $26.72 \mathrm{mg} / \mathrm{kg}$ 까지 지속적으로 안토시아 닌 함량이 감소하는 경향을 나타내었다. 이와 같은 결과는 Park 등(2013)의 연구 보고에서 나타난 결과에서처럼 에탄올 함량이 증가할수록 schizandrin 함량은 증가하였으나, browning index를 지표로 한 안토시아닌 색소 변화는 에탄올의 함량과 온도가 낮 을수록 높게 나타냈다는 결과와는 다른 경향을 나타내었다. 즉, 에탄올을 이용하여 오미자 착즙박을 2 시간 추출한 경우 에탄올 함량에 관계없이 안토시아닌 함량이 일정수준을 유지하다가 추 출 2시간 이후 지속적으로 감소되는 경향을 나타내었다. 이러 한 결과는 열처리에 의한 오미자 색소의 변색 특히, 붉은 색에 대한 손실에 영향을 준 것으로 판단되었으며, 이는 오미자 색 소에 영항을 미치는 요인에 대하여 연구한 Chun 등(2003)의 보 고에 나타난 바와 같이 오미자에 함유된 다양한 물질이 가열시 간이 증가됨에 따라서 오미자 색소 추출물의 가열 변색에 영향 을 미쳐 오미자의 색깔 중 적색(a값)을 급격히 감소시켜서 오 미자의 붉은 색을 나타내는 안토시아닌 성분을 소실시켰다는 보 고와 유사한 결과를 나타낸 것으로 생각되었다.

Table 5 Changes of anthocyanin contents of residue after Omija juice extraction by different extraction methods

\begin{tabular}{ccccc}
\hline \multirow{2}{*}{ Extraction time $(\mathrm{h})$} & \multicolumn{4}{c}{ Anthocyanin $(\mathrm{mg} / \mathrm{kg})$} \\
\cline { 2 - 5 } & $\mathrm{H}_{2} \mathrm{O}$ & $50 \% \mathrm{EtOH}$ & $70 \%$ EtOH & $95 \% \mathrm{EtOH}$ \\
\hline 1 & $66.46 \pm 1.00^{\mathrm{aBB} 1)}$ & $101.70 \pm 13.53^{\mathrm{aA}}$ & $109.32 \pm 7.26^{\mathrm{aA}}$ & $65.46 \pm 16.36^{\mathrm{aB}}$ \\
2 & $63.12 \pm 2.34^{\mathrm{abB}}$ & $107.04 \pm 24.88^{\mathrm{aA}}$ & $115.72 \pm 10.52^{\mathrm{aA}}$ & $62.12 \pm 8.02^{\mathrm{aB}}$ \\
3 & $56.28 \pm 4.51^{\mathrm{abB}}$ & $87.84 \pm 8.02^{\mathrm{aA}}$ & $100.69 \pm 3.17^{\mathrm{abA}}$ & $50.10 \pm 17.71^{\mathrm{abB}}$ \\
4 & $55.27 \pm 4.17^{\mathrm{abB}}$ & $86.83 \pm 2.00^{\mathrm{aA}}$ & $105.37 \pm 1.50^{\mathrm{abA}}$ & $43.53 \pm 22.26^{\mathrm{abB}}$ \\
5 & $54.44 \pm 1.34^{\mathrm{bB}}$ & $80.82 \pm 5.01^{\mathrm{abA}}$ & $93.96 \pm 16.70^{\mathrm{abA}}$ & $54.94 \pm 17.53^{\mathrm{abB}}$ \\
6 & $55.77 \pm 5.34^{\mathrm{abB}}$ & $87.50 \pm 31.53^{\mathrm{aAB}}$ & $103.20 \pm 30.39^{\mathrm{abA}}$ & $54.88 \pm 2.51^{\mathrm{abB}}$ \\
7 & $62.12 \pm 6.68^{\mathrm{abAB}}$ & $81.16 \pm 9.01^{\mathrm{abAB}}$ & $90.84 \pm 16.36^{\mathrm{abcA}}$ & $54.44 \pm 27.05^{\mathrm{abB}}$ \\
8 & $64.62 \pm 7.51^{\mathrm{abA}}$ & $71.25 \pm 22.89^{\mathrm{abA}}$ & $81.49 \pm 5.01^{\mathrm{bcA}}$ & $38.07 \pm 7.01^{\mathrm{abB}}$ \\
9 & $61.79 \pm 12.69^{\mathrm{abB}}$ & $74.25 \pm 11.23^{\mathrm{abAB}}$ & $84.00 \pm 2.17^{\mathrm{bcA}}$ & $26.72 \pm 1.67^{\mathrm{bC}}$ \\
10 & $56.00 \pm 4.87^{\mathrm{abAB}}$ & $47.93 \pm 30.56^{\mathrm{bAB}}$ & $69.13 \pm 2.00^{\mathrm{cA}}$ & $29.06 \pm 12.19^{\mathrm{bB}}$ \\
\hline
\end{tabular}

${ }^{1}$ Means \pm standard deviation $(n=3)$

Superscript letters in a column (a-b) and a row (A-B) indicate significantly at $p<0.05$ by Duncan's multiple comparison 


\section{초 록}

생 오미자를 착즙하고 남은 착즙박을 이용하여 추출조건에 따 른 이화학적 변화를 알아보았다. 즉, 착즙박을 열수, $50 \%$ 에탄 올, $70 \%$ 에탄올 및 $95 \%$ 에탄올을 추출 용매로 사용하였으며, 추출시간은 1 시간에서 10 시간까지 1 시간 간격으로 $60^{\circ} \mathrm{C}$ 에서 정 치 추출하여 여과한 후, 감압 농축하여 제조된 용매별 농축액 을 분석시료로 이용하였다. 오미자에 함유된 유효성분 중 하나 인 schizandrin 함량은 추출 용매에 따라서 열수: $0.52 \mathrm{~g} / 100 \mathrm{~g}$, $50 \%$ 에탄올: $1.79 \mathrm{~g} / 100 \mathrm{~g}, 70 \%$ 에탄올: $2.01 \mathrm{~g} / 100 \mathrm{~g}$ 및 $95 \%$ 에탄올은 $2.37 \mathrm{~g} / 100$ 을 나타내었으며, 열수를 이용하여 추출한 경우보다 에탄올 농도가 증가할수록 schizandrin 함량이 증가하 는 경향을 나타내었다. 총 폴리페놀 함량은 $50 \%$ 에탄올 용매 추출물에서 $16.70 \mathrm{mg} / \mathrm{mL}$ 로 가장 높게 나타났으며, 2,2-diphenyl1-picrylhydrazyl 전자공여소거능에 대한 효과는 분석 시료의 200 $\mathrm{mg} / \mathrm{mL}$ 농도에서 측정하였을 때, $50 \%$ 에탄올 용매 추출물에서 $86.16 \%$ 로 가장 높게 나타내었다. 또한, 안토시아닌 함량은 모 든 용매 추출물이 추출 시간이 증가할수록 감소하는 경항을 보 였다.

Keywords 시잔드린 · 오미자·오미자 착즙액 - 전자공여능 · 총 폴리페놀

\section{References}

Blois MS (1958) Antioxidant determination by the use of a stable free radical. Nature 181: 1199-1200

Choi EO, Lee BS, Park YS, Seo EO, Chung BW (2008) Extraction condition from schizandra chinensis baillon for beverage development of high scizandrin concentration. Korean Soc J Biotechnol Bioeng 23: 271-275

Choi HJ, Choi YW, Baek SY, Kim BS, Ahn SC, Rhee MS, Yoon S (2013) Activity-guided screening of anti-inflammatory compounds from the hexane extracts of schisandra chinensis fruit. J Life Science 23: 311-318

Choi SR, Kim CS, Kim JY, You DH, Kim JM, Kim YS, Song EJ, Kim YG Ahn YS, Choi DG (2011) Changes of antioxidant activity and lignan contents in schisandra chinensis by harvesting times. Korean J Medicinal Crop Sci 19: 414-420

Chun HS, Kim HJ, Cho SB (2003) Effects of selected stabilizers on the color deterioration of crude pigrnent extract from schizandra fruit (Schizandra Fructus). Korean J Food Culture 18: 475-482

Jeong PH, Kim YS, Shin DH (2006) Changes of physicochemical characteristics of schizandra chinensis during postharvest ripening at various temperatures. Koeran J Food Sci Technol 38: 469-474

Jung GT, Ju IO, Choi JS, Hong JS (2000) The antioxudative, antimicrobial and nitrite scavenging effects of schizandra chinensis ruprecht (Omija) seed. Korean J Food Sci Technol 32: 928-935

Kim HS (2013) Comparison of the content of physiological active substances in schisandra fruit tea and ginger tea by extraction method. Dissertation, Dankook University

Kim KS, Kang SS, Ryu SN (2002) Quantitative analysis of lignans from fruits of schizandra chinensis. Kor J Pharmacogn 33: 272-276

Kim KS, Park CG, Ryu SN, Bang JK, Lee BH (2000) Schizandrin, oil compounds, and their extraction yield in fruits of schizandra chinensis baillon. Korean J Crop Sci 45: 158-162

Kim MJ, Park EJ (2010) Antioxidative and antigenotoxic effect of Omija (Schizandra chinensis B.) extracted with various solvents. J Korean Soc Food Sci Nutr 39: 487-493

Kim SI, Sim KH, Ju SY, Han YS (2009) A Study of antioxidative and hypoglycemic activities of Omija (Schizandra chinensis baillon) extract under variable extract conditions. Korean J Food \& Nutr 22: 41-47

Kim YJ, Ha N, Han SH, Jeon JY, Hwang MH, Im YJ, Lee SY, Chae SW, Kim MG (2013) Confirmation of schizandrin as a marker compound in jangsu omija powder. J Korean Soc Food Sci Nutr 42: 244-248

Kim YJ, Han SH, Jeon JY, Hwang MH, Im YJ, Chae SW, Kim MG (2012) Method development of ellagic acid as marker compound for standardization of gochang bokbunja (Rubus coreanus Miquel) as functional ingredient. J. Korean Soc Food Sci Nutr 41: 1554-1558

Ko BS, Park SK, Choi SB, Jun DW, Choi MK, Park SM (2004) A study on hypoglycemic effects of crude extracts of schizandrae fructus. J Korean Soc Appl Biol Chem 47: 258-264

Kwon HJ, Park CS (2006) Biological activities of extracts from Omija (Schizandra chinensis Baillon). Korean J Food Preserv 15: 587-592

Kwon J, Lee SJ, So JN, Oh CH (2001) Effects of schizandra chinensis fructus on the immunoregulatory action and apoptosis of L1210 cells. Korean J Food Sci Technol 33: 384-388

Lee JS, Lee SW (1990) Effects of water extracts in fruits of Omija (Schizandra chinensis baillon) on alcohol metabolism. J Korean Soc Food Culture 5: 259-263

Mok CY (2005) Quality characteristics of instant tea prepared from spraydried Omija (Schizandra chinensis Baillon) extract/grape juice mixture. Food Eng Prog 9: 226-230

Moon YJ, Park S, Sung CK (2003) Effect of ethanolic extract of schizandra chinensis for the delayed ripening Kimchi preparation. Food Sci Nutr 16: $7-14$

Ock ES (1995) Effect of schizandra chinensis extract in hyperlipidemic rats. J Korean Soc Food Nutr 24: 658-662

Park EJ, Ahn JJ, Kwon JH (2013) Effect of reflux conditions on extraction properties and antioxidant activity of freeze dried-schisandra chinensis. Korean J Food Sci. Technol 45: 550-556

Park HM, Hong JH (2014) Physiological activities of aronia melanocarpa extracts on extraction solvents. Korean J Food Preserv 21: 718-726

Rho SN, Oh HS (2002) Effect of Omija (Schizandra chinensis baillon) extracts on the growth of liver cancer cell line SNU-398. Korean J Nutr 35: 201-206

Ryu MJ, Chung HS (2011) Effect on hot water extract of schizandra chinensis on colon cancer cell line. Food Eng Prog 15: 64-69

SAS Institute (1988) SAS/STAT User Guide, release 6.30 edition. Washington, D.C, USA

Singleton VL, Rossi JA (1965) Colorimetry of total phenolics with phosphomolybdic-phosphotungstic acid reagents. Amer J Enol Viticult 16: $144-158$

Sohn HJ, Bock JY (1989) Identification of lignan compounds in fruits of schisandra chinensis baillon by gas chromatography/mass spectrometry. $\mathrm{J}$ Korean Agric Chem Soc 32: 344-349

Song GB (1982) Anthocyanin in cultured omija (schizandra chinensis baillon) and its stability. Dissertation, Chonbuk National University

Whang IT (2002) Study on the effects of fructus schizandrae on the cerebral blood flow and blood pressure. Dissertation, Wonkwang University

Yukinobu I, Heihachiro T, Itiro Y, Hiroshi K (1979) The constituents of schizandra chinensis baill. I. isolation and structure determination of five new lignans, gomisin A, B, C, F and G, and the absolute structure of schizandrin. Chem Pharm Bull 27: 1383-1394 